\title{
Konflik peran ganda pada guru wanita dan kaitannya dengan stres kerja
}

\author{
Nia Adinda Marselina Panjaitan ${ }^{1}$, Perry Boy Chandra Siahaan ${ }^{1 \star}$, Masryna Siagian $^{1}$, Milka Rositi Sianipar $^{2}$ \\ ${ }^{1}$ Fakultas Kesehatan Masyarakat Universitas Prima Indonesia \\ ${ }^{2}$ Fakultas Ekonomi Universitas Prima Indonesia
}

\begin{abstract}
ABSTRAK
Wanita yang mengambil peran sebagai istri dan ibu sekaligus pekerja cenderung membawa mereka pada konflik peran ganda. Studi ini bertujuan untuk melihat hubungan antara konflik peran ganda dengan stres kerja pada guru wanita. Penelitian ini merupakan penelitian kuantitatif observasional dengan desain cross-sectional. Pengambilan sampel dalam penelitian ini adalah dengan menggunakan teknik total sampling di mana seluruh populasi dijadikan sampel yaitu sebanyak 30 orang guru. Pengumpulan data dalam penelitian ini dilakukan dengan menggunakan kuesioner. Data dianalisis dengan menggunakan uji korelasi Gamma dan Somers'd $(\alpha=$ 0,05). Hasil uji statistik menunjukkan bahwa terdapat hubungan yang signifikan antara konflik peran ganda dengan stress kerja pada guru wanita menikah $(\mathrm{p}=0,01)$. Sebagian besar guru wanita tidak dapat menjalankan perannya sebagai orangtua yakni dalam hal mengurus anak saat jam kerja. Selain itu, di masa pandemi seperti ini anak diharuskan belajar secara daring tanpa dampingan orang tua. Hal ini yang memunculkan kekhawatiran pada guru wanita saat bekerja sehingga dapat mengakibatkan terjadinya stres pada guru wanita yang telah menikah.
\end{abstract}

Kata kunci: konflik peran ganda, stres kerja, guru wanita

Women who take on the roles of wife and mother as well as workers tend to lead them to multiple role conflicts. This study aims to examine the relationship between dual role conflict and job stress on female teachers. This study is an observational quantitative study with a cross-sectional design. Sampling in this study was to use a total sampling technique in which the entire population was sampled as many as 30 teachers. The data collection in this study was carried out using a questionnaire. Data were analyzed using Gamma and Somers'd correlation test $(\alpha=0.05)$. The results of statistical tests showed that there was a significant relationship between dual role conflict and work stress on married female teachers $(p=0.01)$. Most female teachers cannot carry out their role as parents, namely in terms of taking care of children during working hours. Additionally, during a pandemic, children must study online without parental assistance. This raises concerns for female teachers while working so that it can lead to stress for married female teachers.

Keywords: dual role conflict, work stress, female teacher

*Alamat korespondensi: perryboy85@yahoo.com

DOI: 10.34012/jpms.v3i2.1840

\section{PENDAHULUAN}

Tekanan antara peran keluarga dan pekerjaan dapat mengarah pada penurunan fisik dan psikologis pekerja wanita. Tekanan yang terjadi pada pekerja wanita yang sudah menikah dan memiliki anak dalam mengembangkan dua peran tersebut dapat menyebabkan timbulnya stres. Konflik antara pekerjaan dan keluarga merupakan salah satu bentuk konflik antar peran di mana tekanan dari pekerjaan mengganggu pelaksanaan peran keluarga dan sebaliknya. Situasi ini akan menimbulkan ketidakpuasan kerja, depresi, dan kemangkiran yang pada akhirnya akan menyebabkan stres kerja. ${ }^{1}$ Penelitian yang dilakukan di Amerika menunjukkan 65\% wanita karir yang mengalami stres kerja diakibatkan oleh konflik peran ganda dan menyebabkan penurunan produktivitas kerja. Wanita yang mengambil peran sebagai istri dan ibu sekaligus pekerja, cenderung membawa mereka pada konflik peran ganda (work- 
family conflict). Kondisi tersebut berkaitan dengan tugas utama mereka sebagai ibu dan istri, namun di luar rumah tetap mempunyai peran lain yaitu wanita karir, maka wanita dijadikan sorotan utama dalam kasus konflik peran ganda, meskipun terkadang laki-laki juga dapat mengalami hal tersebut. ${ }^{2}$

Konflik peran ganda merupakan suatu bentuk tekanan dari pekerjaan dan keluarga yang berkaitan dengan kejadian stres kerja. Dalam hal ini, saat seseorang menghabiskan waktu yang lebih untuk memenuhi salah satu peran maka mereka bisa kekurangan waktu untuk peran yang lainnya. Beberapa faktor penyebab konflik peran ganda yaitu melaksanakan dua peran yang berbeda dalam waktu yang sama, terlalu lelah melakukan salah satu peran sehingga sulit untuk melakukan peran lainnya, dan terlalu fokus melakukan satu peran sehingga meninggalkan peran lainnya. ${ }^{3}$ Penelitian yang dilakukan oleh Azkiyati (2018) tentang hubungan konflik peran ganda dan manajemen waktu dengan stres kerja pada wanita menikah yang berprofesi sebagai guru, diperoleh hasil bahwa ada hubungan positif antara stres kerja dengan konflik peran ganda. Semakin tinggi tingkat konflik peran ganda seseorang, maka akan semakin tinggi pula tingkat stres yang dialami orang tersebut. Begitupula sebaliknya, semakin rendah tingkat konflik peran ganda seseorang, maka akan semakin rendah pula stres yang dialami. ${ }^{4}$ Demikian halnya dengan riset yang dilakukan oleh Weken et.al (2020) tentang hubungan antara beban kerja, konflik peran, dan dukungan sosial dengan stres kerja pada guru di Sekolah Menengah Atas Negeri 1 Manado pada masa pandemi Covid-19, di mana penelitian ini menunjukkan adanya hubungan antara konflik peran dengan stres kerja pada guru di SMA N 1 Manado $(p=0,000)$. Dari 29 responden dengan stres kerja tinggi ada 25 responden $(86,2 \%)$ yang mengalami konflik peran tinggi. ${ }^{5}$

Data Pokok Kemendikbud menunjukkan total keseluruhan guru di Kota Medan berjumlah 27.999 orang pada tahun ajaran 2020/2021, di mana terdapat 6.484 guru laki-laki dan 21.515 guru perempuan. Data tersebut menunjukkan bahwa pada tahun ajaran 2020/2021, guru perempuan lebih mendominasi untuk daerah Kota Medan. ${ }^{6} \mathrm{Hal}$ ini menunjukkan bahwa lebih banyak guru wanita yang menjalankan peran ganda, artinya akan semakin besar risiko seorang guru wanita mengalami stres kerja akibat dari peran ganda tersebut.

Peneliti melakukan survei pendahuluan di Sekolah Global Prima dengan jumlah guru sebanyak 108 orang melalui pemberian kuesioner kepada 30 guru wanita secara acak. Dari kuesioner tersebut diperoleh hasil bahwa 40\% guru wanita mengalami stres ringan dengan gejala yang dirasakan yaitu sering merasa lelah, otot tegang, sakit kepala dan gangguan pencernaan. Selain itu, wawancara juga dilakukan pada 15 guru wanita yang sudah menikah selama 2 hari dengan pertanyaan terkait faktor yang menyebabkan guru wanita mengalami stres kerja. Hasil survei pendahuluan menunjukkan bahwa sebanyak 2 orang guru menyatakan bahwa stres dapat terjadi apabila ada komplain dari orangtua murid, 4 orang guru menyatakan bahwa stres terjadi karena masalah finansial, dan 9 orang guru menyatakan bahwa stres terjadi karena harus mengendalikan 2 peran sekaligus yaitu menjadi seorang istri/ibu di rumah dan menjadi seorang guru di sekolah.

Gejala stres yang dialami oleh guru wanita yang telah menikah tersebut dikategorikan ke dalam indikator fisiologis dan emosional di mana selama 2 minggu terakhir mereka merasakan gangguan fisiologis seperti tengkuk tegang, gangguan pencernaan, serta mudah lelah. Adapun gangguan emosional yang mereka alami yaitu mudah marah dan tersinggung akan hal-hal sepele . Gejala-gejala tersebut juga terlihat pada hasil skor kuesioner yang diperoleh yaitu antara 15-18 dimana skor tersebut memiliki arti bahwa responden mengalami stres ringan.

Penelitian terdahulu mengambil beberapa variabel lain sebagai penyebab terjadinya stres kerja pada guru wanita yang sudah menikah sehingga tidak terfokus pada dua peran yang dimiliki seorang guru wanita yang sudah menikah. Penelitian ini dilakukan berfokus pada satu variabel yang kuat kaitannya dengan yang dialami seorang guru wanita yang sudah menikah yaitu konflik peran ganda. 


\section{METODE}

Penelitian ini merupakan penelitian kuantitatif observasional dengan desain cross-sectional. Lokasi penelitian tepatnya terletak di Sekolah Swasta Global Prima yang berada di Jl. Brigjend Katamso No.282-283, Sei Mati, Kec. Medan Maimun, Kota Medan. Penelitian dilaksanakan pada bulan Juni 2021. Populasi penelitian ini adalah guru yang berjenis kelamin wanita yang dipastikan sudah menikah atau memiliki anak dan tinggal bersama suami atau anaknya, dengan masa kerja masih aktif yaitu sebanyak 30 orang. Pengambilan sampel dalam penelitian ini adalah dengan menggunakan teknik total sampling di mana seluruh populasi dijadikan sampel yaitu sebanyak 30 orang guru. Pengumpulan data dalam penelitian ini dilakukan dengan wawancara yang dibantu dengan menggunakan kuesioner. Hasil penelitian ini dianalisis dengan menggunakan uji korelasi Gamma dan Somers'd $(\alpha=0,05)$.

\section{HASIL}

Studi ini bertujuan untuk melihat hubungan antara konflik peran ganda dan kaitannya dengan stres kerja pada guru wanita di Sekolah Swasta Global Prima. Dari hasil penelitian terlihat bahwa berdasarkan distribusi frekuensi kelompok usia, responden yang paling banyak adalah kelompok usia 26-35 tahun sebanyak 17 orang $(56,7 \%)$ dan responden yang paling sedikit adalah kelompok usia 4655 sebanyak 1 orang $(3,3 \%)$.

Tabel 1. Karakteristik responden

\begin{tabular}{|c|c|c|}
\hline Variabel & Jumlah & Persentase \\
\hline \multicolumn{3}{|l|}{ Usia } \\
\hline $26-35$ tahun & 17 & 56,7 \\
\hline $36-45$ tahun & 12 & 40,0 \\
\hline $46-55$ tahun & 1 & 3,3 \\
\hline \multicolumn{3}{|l|}{ Pendidikan terakhir } \\
\hline SMA & 2 & 6,7 \\
\hline D3 & 2 & 6,7 \\
\hline S1 & 20 & 66,7 \\
\hline $\mathrm{S} 2$ & 6 & 20,0 \\
\hline \multicolumn{3}{|l|}{ Masa kerja } \\
\hline $1-5$ tahun & 16 & 53,3 \\
\hline $6-10$ tahun & 13 & 43,3 \\
\hline$>11$ tahun & 1 & 3,3 \\
\hline \multicolumn{3}{|l|}{ Jumlah anak } \\
\hline Belum memiliki & 8 & 26,7 \\
\hline 1 orang & 10 & 33,3 \\
\hline 2 orang & 7 & 23,3 \\
\hline 3 orang & 4 & 13,3 \\
\hline$>3$ orang & 1 & 3,3 \\
\hline \multicolumn{3}{|l|}{ Konflik peran ganda } \\
\hline Ringan & 13 & 43,3 \\
\hline Sedang & 8 & 26,7 \\
\hline Berat & 9 & 30,0 \\
\hline \multicolumn{3}{|l|}{ Stres kerja } \\
\hline Ringan & 13 & 43,3 \\
\hline Sedang & 9 & 30,0 \\
\hline Berat & 8 & 26,7 \\
\hline Sangat Berat & 0 & 0 \\
\hline
\end{tabular}

Berdasarkan distribusi frekuensi masa kerja, responden yang paling banyak adalah responden yang bekerja selama 1-5 tahun sebanyak 16 orang $(53,3 \%)$ dan yang paling sedikit adalah responden yang bekerja selama $>11$ tahun sebanyak 1 orang (3,3\%). Berdasarkan distribusi frekuensi jumlah anak, responden yang paling banyak adalah responden yang memiliki jumlah anak 1 orang sebanyak 10 orang $(33,3 \%)$ dan yang paling sedikit adalah responden dengan jumlah anak $>3$ orang sebanyak 1 orang $(3,3 \%)$.

Berdasarkan distribusi frekuensi konflik peran ganda, responden yang paling banyak adalah responden yang mengalami konflik peran ganda rendah sebanyak 13 orang $(43,3 \%)$ dan yang paling sedikit adalah responden yang mengalami konflik peran ganda sedang sebanyak 8 orang $(26,7 \%)$.

Berdasarkan distribusi frekuensi stres kerja, responden yang paling banyak adalah responden yang mengalami stres kerja rendah sebanyak 13 orang $(43,3 \%)$ dan yang lebih sedikit adalah responden yang mengalami stres kerja tinggi sebanyak 8 orang $(26,7 \%)$. 
Selanjunya analisis bivariat dilakukan untuk mengetahui hubungan antara konflik peran ganda dengan stres kerja pada guru wanita yang sudah menikah dengan menggunakan uji Gamma dan Somers'd.

Tabel 2. Hasil uji bivariat

\begin{tabular}{ccccccccc}
\hline \multirow{2}{*}{$\begin{array}{c}\text { Konflik } \\
\text { peran ganda }\end{array}$} & \multicolumn{9}{c}{ Stres Kerja } & \multicolumn{2}{c}{ Berat } & \multirow{2}{*}{ p-value } \\
\cline { 2 - 7 } & $\mathrm{n}$ & $\%$ & $\mathrm{n}$ & $\%$ & $\mathrm{n}$ & $\%$ & \\
\hline Ringan & 8 & 61,5 & 4 & 30,8 & 1 & 7,7 & \\
Sedang & 3 & 37,5 & 2 & 25 & 3 & 37,5 & 0,01 \\
Berat & 2 & 22,2 & 3 & 33,3 & 4 & 44,5 & \\
\hline
\end{tabular}

Pada tabel 2 dapat dilihat bahwa dari 13 responden dengan konflik peran ganda ringan, paling banyak adalah responden yang mengalami stres kerja ringan sebanyak 8 orang $(61,5 \%)$ dan yang paling sedikit adalah responden yang mengalami stres kerja berat sebanyak 1 orang $(7,7 \%)$. Responden dengan konflik peran ganda sedang sebanyak 8 orang, paling banyak adalah responden yang mengalami stres kerja ringan sebanyak 3 orang $(37,5 \%)$ dan mengalami stres kerja berat sebanyak 3 orang $(37,5 \%)$ dan yang paling sedikit adalah responden yang mengalami stres kerja sedang sebanyak 2 orang (25\%). Responden dengan konflik peran ganda berat sebanyak 9 orang, yang paling banyak adalah responden yang mengalami stres kerja berat sebanyak 4 orang $(37,5 \%)$ dan yang paling sedikit adalah responden yang mengalami stres kerja ringan sebanyak 2 orang $(22,2 \%)$.

Dengan nilai korelasi yang diperoleh sebesar 0,35 dan diperoleh nilai approx sig sebesar $0,01(\alpha<$ 0.05). Dapat disimpulkan bahwa terdapat hubungan yang signifikan antara konflik peran ganda dengan stress kerja pada guru wanita menikah di Sekolah Swasta Global Prima.

\section{PEMBAHASAN}

Wanita telah membuktikan eksistensinya dalam dunia pekerjaan, tidak jarang banyak dari mereka yang memiliki peran ganda. Peran ganda wanita merupakan salah satu konsep yang ditawarkan oleh dunia ketenagakerjaan beberapa tahun ini. Banyak wanita yang mengembangkan karir dengan bekerja di luar rumah. Pada saat wanita menjalani karirnya wanita juga dituntut untuk dapat berperan sebagai istri, serta ibu yang mengasuh dan merawat anak. Meskipun ada perubahan status, tanggung jawab primer untuk mengelola kegiatan rumah dan keluarga serta beristirahat bagi wanita yang memiliki peran ganda tetaplah ada, bahkan ketika dia bekerja penuh waktu di luar rumah, dilihat dari kenyataan yang terjadi saat ini, maka sangat penting untuk memerhatikan konflik peran ganda khususnya pada wanita.

Konflik peran ganda yang dialami oleh wanita akan memengaruhi kondisi psikologis karyawan, dan tidak menutup kemungkinan menyebabkan stres, stres juga berpengaruh secara tidak langsung terhadap kinerja karyawan dan tujuan organisasi. Stres menjadi salah satu masalah yang paling sering dihadapi oleh setiap individu dalam menyelesaikan pekerjaan. Stres dapat digambarkan sebagai perasaan tegang, gelisah, atau khawatir. ${ }^{7}$

Hasil penelitian ini menunjukkan bahwa ada hubungan antar konflik peran ganda dengan stres kerja pada guru wanita menikah di Sekolah Global Prima. Responden dengan konflik peran ganda ringan dapat mengalami stres kerja berat. Hal ini bisa disebabkan oleh faktor lain seperti masalah finansial, hubungan interpersonal, dan pengembangan karir. Responden dengan konflik peran ganda berat dapat mengalami stres kerja ringan karena dipengaruhi oleh cara seseorang dalam me-manage stres dalam dirinya seperti dengan cara menyediakan me time dan quality time dengan keluarga sebagai batasan antara waktu bersama keluarga dengan pekerjaan. Studi menunjukkan perempuan yang bekerja dan berkeluarga memiliki kinerja yang berbeda dengan perempuan yang bekerja tetapi belum menikah. 
Jika peran ganda ini tidak ditangani dengan baik, maka akan menimbulkan konflik dan mempengaruhi kinerja. ${ }^{8}$

Peran ganda memang memberikan konsekuensi bagi ibu rumah tangga yang bekerja. Di satu sisi wanita mencari nafkah untuk membantu suami, namun di sisi lain wanita harus bisa melaksanakan tanggung jawabnya sebagai istri dan ibu. Hal ini terlihat dari hasil kuesioner penelitian yang menunjukkan bahwa sebagian besar guru wanita tidak dapat menjalankan perannya sebagai orangtua yakni dalam hal mengurus anak, guru wanita harus menggunakan tenaga pengasuh ataupun memberdayakan anggota keluarga untuk mengurus anak saat jam kerja. Selain itu, di masa pandemi seperti ini anak diharuskan belajar secara daring tanpa dampingan orang tua. Hal ini yang memunculkan kekhawatiran pada guru wanita saat bekerja sehingga dapat mengakibatkan terjadinya stres pada guru wanita yang telah menikah.

Temuan studi Haekal dan Fitri (2020) menunjukkan bahwa wanita yang berprofesi sebagai dosen mengalami tekanan yang cukup besar selama pandemi COVID karena harus mengerjakan pekerjaan domestik di jam-jam kerja. Pada dosen yang tinggal di rumah pribadi, isu yang muncul adalah terkait perawatan anak. Mereka kesulitan merawat anak, apalagi bagi dosen yang memiliki anak lebih dari satu, dan ditambah lagi jika anak-anak sudah bersekolah. Beban perawatan ditambah dengan pendidikan. Hal ini terasa memberatkan apabila suami tidak suportif dalam membantu. ${ }^{9}$

Guru pra-sekolah perempuan melaporkan bahwa COVID-19 telah meningkatkan beban kerja dan stres pengasuhan anak pada guru wanita yang mengajar di TK. Selain itu, kelebihan kerja secara negatif berkaitan dengan kepuasan kerja melalui hubungan positifnya dengan konflik pekerjaan-kekeluarga. ${ }^{10}$

\section{KESIMPULAN}

Studi menyimpulkan bahwa konflik peran ganda berkaitan dengan stres kerja pada guru wanita di Sekolah Swasta Global Prima. Sebagian besar guru wanita tidak dapat menjalankan perannya sebagai orangtua yakni dalam hal mengurus anak saat jam kerja. Selain itu, di masa pandemi seperti ini anak diharuskan belajar secara daring tanpa dampingan orang tua. Hal ini yang memunculkan kekhawatiran pada guru wanita saat bekerja sehingga dapat mengakibatkan terjadinya stres pada guru wanita yang telah menikah.

\section{REFERENSI}

1. Akbar DA. Konflik Peran Ganda Karyawan Wanita dan Stres Kerja. An Nisa’a J Kaji Gend dan Anak. 2017;12(1):33-48.

2. Kalendesang M., Bidjuni H, Malara R. Hubungan Konflik Peran Ganda Perawat Wanita Sebagai Care Giver Dengan Stres Kerja di Ruangan Rawat Inap Rumah Sakit Jiwa Prof. Dr. V. L. Ratumbuysang Provinsi Sulawesi Utara. J Keperawatan UNSRAT. 2017;5(1):108714.

3. Shabani MG, Karaminejad J, Namjoo B, Namjoo F. Investigating the Relationship between Work-Family Conflict and Marital Conflict with a Mediating Role of Psychological Capital TT. J Assess Res Couns Psychol [Internet]. 2019 Nov 1;1(1):1-13. Available from: http://jarcp.ir/article-1-21-en.html

4. Azkiyati N. Hubungan Konflik Peran Ganda dan Manajemen Waktu dengan Stress Kerja Pada Wanita Menikah yang Berprofesi Sebagai Guru. Psikologi. 2018;6(1):59-71.

5. Weken ME, Mongan AE, Kekenusa JS. Hubungan antara Beban Kerja, Konflik Peran, dan Dukungan Sosial dengan Stres Kerja Pada Guru di Sekolah Menengah Atas Negeri 1 Manado Pada Masa Pandemi Covid-19. J Public Heal Community Med. 2020;1(4):80-8.

6. Kementerian Pendidikan dan Kebudayaan. Data Pokok Pendidikan (DAPODIK) [Internet]. 2020. p. 1. Available from: https://bppauddikmasntt.kemdikbud.go.id/index.php/ult/11-artikel/59-data-pokokpendidikan-dapodik

7. Sari RK, Nasir A, Amri. Pengaruh Konflik Peran Ganda dan Stres Kerja Terhadap Kinerja Pemeriksa BPK 
RI Perwakilan Provinsi Aceh. J Manaj. 2014;3(2):29-34.

8. Nasekhah AD. Pengaruh Peran Ganda Terhadap Kinerja Karyawan Wanita di Tempat Kerja di LPP RRI Yogyakarta. Diklus J Pendidik Luar Sekol. 2017;1(2).

9. Haekal M, Fitri A. Dilema Peran Ganda Dosen Perempuan Selama Pandemi Covid-19 di Indonesia. JAS-PT (Jurnal Anal Sist Pendidik Tinggi Indones. 2020;4(2):171.

10. Parlak S, Celebi Cakiroglu O, Oksuz Gul F. Gender roles during COVID-19 pandemic: The experiences of Turkish female academics. Gender, Work Organ [Internet]. 2021 Jul 1;28(S2):461-83. Available from: https://doi.org/10.1111/gwao.12655 